\title{
Methodical Aspects of Assessment of the Level of Economic Security on the Forest Sector of the Economy
}

\begin{abstract}
Submitted 06/01/19, 1st revision 26/02/19, 2nd revision 11/04/19, accepted 02/06/19
Kolesnichenko E.A. ${ }^{1}$, Kharchenko N.N. ${ }^{2}$ Harada G.I. ${ }^{3}$, Trofimov M.N. ${ }^{4}$

Abstract:

Purpose: The main objective of this study is to develop a methodology for monitoring threats to the economic security of the forestry sector.

Design/Methodology/Approach: Based on the principle of consistency, the authors proposed a proper algorithm for assessing the level of economic security of forestry which includes a list of parameters and evaluation criteria. The researchers also described the stages of its implementation and interpreted the results.

Findings: The researchers considered the objective and subjective factors that have a negative impact on the forestry sector itself and on the effectiveness of the use of forest resources. The authors argue that there are two groups of threats to the economic security: threats to the forestry sector itself and threats related to the use of forest resources.

Practical Implications: The study has practical significance as its results may be used both in forestry to assess the level of economic security of the industry, and in other industries.

Originality/Value: The authors contributed to the development of methods for monitoring the threats to economic security in the forestry sector. These methods are aimed at identifying the main risks to the development of the forestry sector that belong to two different groups. The researchers developed the criteria for assessing possible risks and threats to the economic security of the forestry sector.
\end{abstract}

Keywords: Economic security, forest sector, factors of economic security, threat.

JEL Codes: C14, C81, E61, Q23, Q51.

Paper Type: Research article in Special Issue dedicated to Russian Economy.

Section 7: Economic Development.

\footnotetext{
${ }^{1}$ Doctor of Science (Economics), Professor, Head of Chair "Management of Human resource”, Tambov state university named after G.R. Derzhavin, Tambov, Russia, ekolesnichenko@live.ru

${ }^{2}$ Doctor of Science (Biology), Professor, Voronezh State University of Forestry and Technologies named after G.F. Morozov, Voronezh, Russia, forest.vrn@ gmail.com ${ }^{3}$ Doctor of Science (Economics), Associate Professor, Professor of Department of Economic Security, Ryazan branch of the Moscow University of the Ministry of Internal Affairs of Russia named afterV.Ya. Kikotya, Ryazan, Russia, guseingenta@gmail.com ${ }^{4}$ Candidate of Economics Science, Associate Professor, Department of Economic Security, Ryazan branch of the Moscow University of the Ministry of Internal Affairs of Russia named after V.Ya. Kikotya, Ryazan, Russia, trofimov_fanatlk@mail.ru
} 


\section{Introduction}

The unprecedented nature of climate change in modern economic conditions is a threat to the effective development of forestry, which is aggravated by the increasing anthropogenic pressure in the field of forest management. Under current economic conditions, the development of organizational and methodological tools for identifying and assessing the threats increasing from climate change and increasing anthropogenic pressures and forming on this basis strategies to manage emerging economic security risks in some of the most climate-dependent industries, including forestry, becomes an urgent task (Konstantinov and Kolesnichenko, 2016).

Forming strategies for effective development of forestry and, as a result, increasing the economic security of the national economy in the field of forest management, based on reducing the climate risks of forestry development, involves the development of scientific methods for assessing the risks, vulnerability and potential benefits of the expected climate changes, taking into account natural geographical, economic, social and other features of a particular region or field of industry, but also the formation of a differentiated multi-level forest management mechanism, the implementation of which is aimed not just at the leveling of emerging threats, but also on their preventive elimination (Kolesnichenko and Osmanov, 2015). Thus, it becomes necessary to develop a methodology for monitoring threats to economic security.

\section{Methodology of the Research}

Enough research has been devoted to the study of threats to the economic security of forestry. In accordance with the provisions put forward by Utkin and Denisov (2002), a possible algorithm for analyzing the impact of threats to economic security may be as follows: identifying the list of factors that negatively affect each functional component of economic security. In this case, it is advisable to separate the objective and subjective negative impacts; identifying the probability of occurrence and the impact of individual negative factors (the threat of their occurrence), as well as an assessment of possible damage in case of their occurrence in order to assess the likely extent of damage.

Research methodology involves three phases of work. At the first stage, a comparative analysis of the state of the problem and the conduct of desk research were carried out. The second stage involves the development of the author's methodology for assessing threats to economic security. The third stage is data processing and approbation of the proposed methodology, statistical data processing using mathematical and statistical methods and presentation of results. To assess the probability of threats occurrence to economic security, it is advisable to determine the values of the criteria on the Harrington scale, supplemented with a verbal description of each interval of the scale, since verbal-numeric scales are used mainly in cases where the assessment of the criterion is subjective, based on expert experience and knowledge (Bespalov, 2007). 
The numerical values of the Harrington scale are derived from the analysis of a large array of statistical data; according to this, the Harrington scale is universal and can be used to evaluate many qualitative indicators (Barlou, 1969) (Table 1).

Table 1. Quantitative scale for assessing possible threats to economic security (Barlou R. Mathematical theory of reliability, 1969)

\begin{tabular}{|l|c|}
\hline The likelihood of the risk occurring & The coefficient used in the calculations \\
\hline Critical & 0,85 \\
\hline Very high & 0,9 \\
\hline High & 0,95 \\
\hline Significant & 0,99 \\
\hline Low & 1 \\
\hline
\end{tabular}

\section{Results and Discussions}

In relation to this study, monitoring is a process of continuous assessment of emerging threats in the field of forestry (based on the collection of information and the calculation of certain indicators) in order to assess and improve the economic security of forestry. It should be noted that monitoring of threats to economic security should include the following main procedures (Kolesnichenko and Radyukova, 2017):

- Selection of the object of observation; in this case, in the first stage of the analysis the object of observation will be the forest resources of the territories. In the subsequent stages of the analysis, it will be both forest resources and enterprises operating within the forest fund of the Russian Federation;

- Compilation of an information model for monitoring. Further material will be devoted to this aspect. The information model will be the set of characteristics of the safe development of the forest sector of the economy;

- Planning measurement parameters. This aspect is the most difficult, since the parameters of change are closely interrelated with the development of threshold values for assessing the level of economic security. According to the authors, the threshold value for the assessment should be individual for each specific indicator and for each specific territory, which is determined by the specificity of the distribution of forest resources and the variation of the values of the indicators;

- Direct monitoring of the object of research on a number of parameters presented. In this case, it is important to choose a monitoring tool;

- presentation of the obtained monitoring results in a convenient form for further processing.

An algorithm was chosen as a tool for monitoring threats to economic security in the forest sector of the economy in the context of climate change and increasing anthropogenic pressure. When forming the algorithm, the authors proceeded from the following provisions (Kolesnichenko and Osmanov, 2015): 
1. It is advisable to assess the level of economic security for a certain territory, which has its own characteristics of the functioning of the forest sector (multi-forest or low forest zone, etc.) and economic activities in the forest sector, data about which is accumulated within a certain region.

2. It is advisable to divide the entire set of threats to economic security into two groups:

i) threats to the forest sector itself. These threats are the most significant. In the presented algorithm, the impact of threats on this component is characterized by the indicator "economic security of forest resources by environmental component" (for example, the threat of reducing the forest cover of the territory or changing the qualitative composition of wood under the influence of any determinant factors. These are threats resulting from objectively existing conditions (even if initially they had an anthropogenic nature) and they are not amenable to direct managerial influence with the purpose of leveling);

ii) threats arising in the use of forest resources. In the algorithm, the impact of threats is characterized by the indicator "economic security of forest resources in the economic component" (for example, a decrease in the profitability of business structures or payments to the budget can serve as an indicator of increased threats. These factors are subjective (they are the result of management impact on the forest complex or its components, also they can be influenced by the management apparatus).

3. To assess the level of economic security of the forest sector, interrelated indicators of the first and second order will be applied (according to the degree of consolidation), these indicators may be interrelated, interdependent, and in various situations characterized by varying degrees of generalization. For example, in some cases, forest fires are an objective characteristic of forestry - the cause of a decrease in forest land coverage, in others - forest fires are a subjective factor characterizing the negative nature of anthropogenic impact.

4. When monitoring threats to economic security, the key principle is consistency. When adopting aggregated indicators of the value corresponding to a high level of economic security, further analysis of this component is not required. When adopting aggregated indicators of the value corresponding to a low or insufficient level of economic security, a subsequent analysis of threats of a lower order is necessary.

The development of a methodology for monitoring threats to economic security in the forest sector of the economy includes (Konstantinov and Kolesnichenko, 2016):

1. Definition of the main characteristics of risks in relation to the development of the forest sector, grouped in two key areas (subjective - characterizing the economic component in the functioning of the forest complex, and objective - characterizing 
the development of the forest complex itself as a natural category) and disclosure of their content.

2. Identification of indicators that most fully reflect the possibility of a risk in each of the proposed areas.

3. Determination of parameters for assessing the values of risk indicators of threats to economic security and assigning them a scoring.

4. Development of criteria for identifying the obtained values of indicators for assessing the possible risks of threats to the economic security of forestry.

According to the authors, the key indicators of sustainable and safe development of the forest sector are two indicators: the forest cover of the territory and the stock of wood (Morkovina and Drapalyuk, 2017):

1. Forest area. The criteria for identifying the indicator of forest cover are: the level of compliance of the forest cover with the average value for $n$ years; the level of compliance of forest cover with the ecological minimum (Table 2).

Table 2. Identification parameters of criteria for assessing the level of economic security in terms of forest cover (developed by the authors)

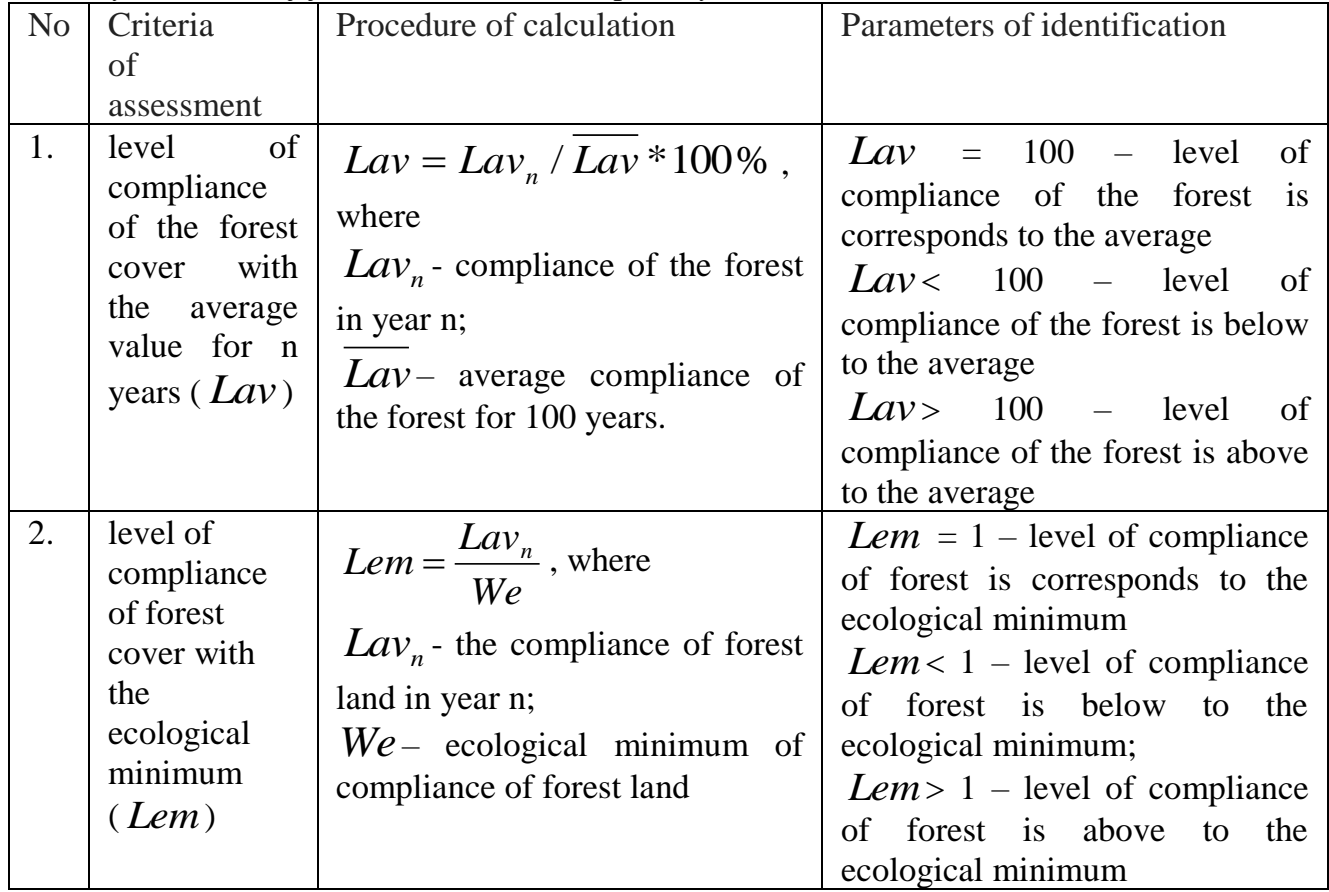


2. Wood stock. This criterion characterizes the amount of wood per 1 hectare of forest plantations, which varies with their age: the level of compliance of the wood supply with the standard value; growth rate of wood stock per year (table 3).

Table 3. Identification parameters of criteria for assessing the level of economic security in terms of wood stock (developed by the authors)

\begin{tabular}{|c|c|c|c|}
\hline No & $\begin{array}{l}\text { Criteria } \\
\text { of assessment }\end{array}$ & Procedure of calculation & Parameters of identification \\
\hline 1. & $\begin{array}{l}\text { the level of } \\
\text { compliance of } \\
\text { the wood } \\
\text { supply with } \\
\text { the standard } \\
\text { value ( } L S S \text { ) }\end{array}$ & $\begin{array}{l}L s S=S w_{n} / S n * 100 \%, \\
\text { where } \\
S w_{n}-\text { wood stock of the area in } \\
\text { year n; } \\
S n-\text { normative value of the wood } \\
\text { stock of the area }\end{array}$ & $\begin{array}{l}\text { LSS }=100-\text { level of } \\
\text { compliance of the wood is } \\
\text { corresponds to normative } \\
\text { value; } \\
L S S<100-\text { level of } \\
\text { compliance of the wood is } \\
\text { below to normative value; } \\
L s s>100-\text { level of } \\
\text { compliance of the wood is } \\
\text { above to normative value }\end{array}$ \\
\hline 2 & $\begin{array}{lr}\text { growth rate of } \\
\text { wood } & \text { stock } \\
\text { per } & \text { year } \\
(R g s) & \end{array}$ & $\begin{array}{l}R g S=\frac{S w_{n}}{S w_{n-1}} * 100 \%-100 \%, \\
\text { where } \\
S w_{n}-\text { wood stock of the area in } \\
\text { year n; } \\
S w_{n-1}-\text { wood stock of the area in } \\
\text { previous year }\end{array}$ & $\begin{array}{l}R g S=0-\text { growth rate of } \\
\text { wood stock is missing; } \\
R g s<0-\text { growth rate of } \\
\text { wood stock is reduced; } \\
R g S>0-\text { growth rate of } \\
\text { wood stock is grows }\end{array}$ \\
\hline
\end{tabular}

Let us turn to the criteria and indicators characterizing the economic security of forest resources by the economic component. The main indicators characterizing this component are:

3. Profitability of entrepreneurial activities in forestry: the dynamics of the share of unprofitable entrepreneurial structures operating in the forest sector of the economy; dynamics of growth of the average profit of business structures in the forest sector of the economy for the year (Table 4).

Table 4. Identification parameters of the criteria for assessing the level of economic security by the indicator of business profitability (developed by the authors)

\begin{tabular}{|c|c|c|c|}
\hline No & $\begin{array}{l}\text { Criteria } \\
\text { assessment }\end{array}$ & Procedure of calculation & \\
\hline 1. & $\begin{array}{l}\text { the dynamics the } \\
\text { share of } \\
\text { unprofitable } \\
\text { entrepreneurial } \\
\text { structures }\end{array}$ & $\begin{array}{l}\text { Due }=\frac{U e_{n}}{U e_{n-1}} * 100 \%-100 \% \text {, where } \\
U e_{n}-\text { the share of unprofitable } \\
\text { entrepreneurial structures operating }\end{array}$ & $\begin{array}{l}\text { Due }=0-\text { the share of } \\
\text { unprofitable } \\
\text { entrepreneurial } \\
\text { structures operating in } \\
\text { the forest sector of the }\end{array}$ \\
\hline
\end{tabular}




\begin{tabular}{|c|c|c|c|}
\hline & $\begin{array}{l}\text { operating in the } \\
\text { forest sector of the } \\
\text { economy (Due) }\end{array}$ & $\begin{array}{l}\text { in the forest sector of the economy } \\
\text { in year n; } \\
U e_{n-1}-\text { the share of unprofitable } \\
\text { entrepreneurial structures operating } \\
\text { in the forest sector of the economy } \\
\text { in previous year }\end{array}$ & $\begin{array}{l}\text { economy is absent; } \\
\text { Due }<0 \\
\text { unprofitable } \\
\text { entrepreneurial } \\
\text { structures operating in } \\
\text { the forest sector of the } \\
\text { economy in } \\
\text { reduced; } \\
\text { Due }> \\
\text { unprofitable } \\
\text { entrepreneurial } \\
\text { structures operating in } \\
\text { the forest sector of the } \\
\text { economy in is grows }\end{array}$ \\
\hline 2 & $\begin{array}{l}\text { dynamics of } \\
\text { growth of average } \\
\text { profit of business } \\
\text { structures in the } \\
\text { forest sector of the } \\
\text { economy in a year } \\
(\text { Dap })\end{array}$ & $\begin{array}{l}\text { Dap }=\frac{A p_{n}}{A p_{n-1}} * 100 \%-100 \% \text {, where } \\
A p_{n}-\text { average profit of business } \\
\text { structures in the forest sector of the } \\
\text { economy in year } \mathrm{n} \text {; } \\
A p_{n-1}-\text { average profit of business } \\
\text { structures in the forest sector of the } \\
\text { economy in previous year }\end{array}$ & $\begin{array}{l}\text { Dap }=0 \text { - the growth } \\
\text { of average profit is } \\
\text { absent; } \\
\text { Dap }<0 \text { - the average } \\
\text { profit is reduced; } \\
\text { Dap }>0 \text { - the average } \\
\text { profit is growing }\end{array}$ \\
\hline
\end{tabular}

4. The volume of revenues to the budget from the use of forest resources - the dynamics of growth in revenues to the budget from the use of forest resources (table 5).

Table 5. Identification parameters of criteria for assessing the level of economic security by the volume indicator of revenues to the budget from the use of forest resources (developed by the authors)

\begin{tabular}{|c|c|c|c|}
\hline No & $\begin{array}{l}\text { Criteria of } \\
\text { assessment }\end{array}$ & Procedure of calculation & $\begin{array}{l}\text { Parameters of } \\
\text { identification }\end{array}$ \\
\hline 1. & $\begin{array}{l}\text { the dynamics } \\
\text { of growth in } \\
\text { revenues to } \\
\text { the budget } \\
\text { from the use } \\
\text { of forest } \\
\text { resources } \\
(D r b)\end{array}$ & $\begin{array}{l}D r b=\frac{R b_{n}}{R b_{n-1}} * 100 \%-100 \%, \\
\text { where } \\
R b_{n} \text { - volume of revenues to the budget } \\
\text { from the use of forest resources in year } \\
\mathrm{n} ; \\
R b p_{n-1}-\text { volume of revenues to the } \\
\text { budget from the use of forest resources } \\
\text { in previous year }\end{array}$ & $\begin{array}{l}D r b=0 \text { - the growth in } \\
\text { revenues to the budget } \\
\text { from the use of forest } \\
\text { resources is absent; } \\
D r b<0 \text { - the volume of } \\
\text { revenues to the budget } \\
\text { from the use of forest } \\
\text { resources is reduced; } \\
D r b>0 \text { - the volume of } \\
\text { volume of revenues to the } \\
\text { budget from the use of } \\
\text { forest resources is grows }\end{array}$ \\
\hline
\end{tabular}


The corresponding estimates of the level of economic security for each of the parameters are presented in Table 6.

Table 6. Estimates of the level of economic security in the forest sector of the economy by relevant parameters (developed by the authors)

\begin{tabular}{|c|c|c|c|}
\hline No & $\begin{array}{l}\text { Criteria } \\
\text { assessment }\end{array}$ & Criteria of assessment & $\begin{array}{l}\text { The level of } \\
\text { economic } \\
\text { security }\end{array}$ \\
\hline 1 & $\begin{array}{l}\text { level of } \\
\text { compliance of the } \\
\text { forest cover with } \\
\text { the average value } \\
\text { for } \mathrm{n} \text { years } \\
(L a v)\end{array}$ & $\begin{array}{l}L a v=100-\text { level of compliance of the } \\
\text { forest is corresponds to the average } \\
L a v<100-\text { level of compliance of the } \\
\text { forest is below to the average } \\
L a v>100-\text { level of compliance of the } \\
\text { forest is above to the average }\end{array}$ & $\begin{array}{l}\text { Average } \\
\text { Low } \\
\text { High }\end{array}$ \\
\hline 2 & $\begin{array}{l}\text { level of } \\
\text { compliance of } \\
\text { forest cover with } \\
\text { the ecological } \\
\text { minimum ( Lem })\end{array}$ & $\begin{array}{l}\text { Lem }=1-\text { level of compliance of forest is } \\
\text { corresponds to the ecological minimum } \\
\text { Lem }<1-\text { level of compliance of forest is } \\
\text { below to the ecological minimum; } \\
\text { Lem }>1-\text { level of compliance of forest is } \\
\text { above to the ecological minimum }\end{array}$ & $\begin{array}{l}\text { Low } \\
\text { Very low } \\
\text { Average }\end{array}$ \\
\hline 3 & $\begin{array}{l}\text { the level of } \\
\text { compliance of the } \\
\text { wood supply with } \\
\text { the standard value } \\
(L S S \text { ) }\end{array}$ & $\begin{array}{l}L S S=100-\text { level of compliance of the } \\
\text { wood is corresponds to normative value; } \\
L S S<100-\text { level of compliance of the } \\
\text { wood is below to normative value; } \\
L S S>100-\text { level of compliance of the } \\
\text { wood is above to normative value }\end{array}$ & $\begin{array}{l}\text { Average } \\
\text { Low } \\
\text { High }\end{array}$ \\
\hline 4 & $\begin{array}{l}\text { growth rate of } \\
\text { wood stock per } \\
\text { year }(R g s)\end{array}$ & $\begin{array}{l}R g s=0-\text { growth rate of wood stock is } \\
\text { missing; } \\
R g s<0-\text { growth rate of wood stock is } \\
\text { reduced; } \\
\operatorname{Rg} s>0-\text { growth rate of wood stock is } \\
\text { grows }\end{array}$ & $\begin{array}{l}\text { Low } \\
\text { Very low } \\
\text { Average }\end{array}$ \\
\hline 5 & $\begin{array}{l}\text { the dynamics the } \\
\text { share of } \\
\text { unprofitable } \\
\text { entrepreneurial } \\
\text { structures } \\
\text { operating in the } \\
\text { forest sector of } \\
\text { the economy } \\
(\text { Due })\end{array}$ & $\begin{array}{l}\text { Due }=0-\text { the share of unprofitable } \\
\text { entrepreneurial structures operating in the } \\
\text { forest sector of the economy is absent; } \\
\text { Due }<0 \text { - of unprofitable entrepreneurial } \\
\text { structures operating in the forest sector of } \\
\text { the economy in is reduced; } \\
\text { Due }>0 \text { - of unprofitable entrepreneurial } \\
\text { structures operating in the forest sector of } \\
\text { the economy in is grows }\end{array}$ & Average \\
\hline 6 & $\begin{array}{l}\text { dynamics of } \\
\text { growth of average } \\
\text { profit of business } \\
\text { structures in the }\end{array}$ & $\begin{array}{l}\text { Dap }=0 \text { - the growth of average profit is } \\
\text { absent; } \\
\text { Dap }<0 \text { - the average profit is reduced; }\end{array}$ & $\begin{array}{l}\text { Low } \\
\text { Very low } \\
\text { Average or High }\end{array}$ \\
\hline
\end{tabular}




\begin{tabular}{|l|l|l|l|}
\hline $\begin{array}{l}\text { forest sector of } \\
\text { the economy in a } \\
\text { year (Dap) }\end{array}$ & $\begin{array}{l}\text { Dap }>0 \text { - the average profit is growing } \\
\text { the dynamics of } \\
\text { growth in } \\
\text { revenues to the } \\
\text { budget from the } \\
\begin{array}{l}\text { use of forest } \\
\text { resources }(D r b)\end{array}\end{array}$ & $\begin{array}{l}\text { Drb }=0 \text { - the growth in revenues to the } \\
\text { budget from the use of forest resources is } \\
\text { absent; } \\
\text { Dudget from the use of forest resources is } \\
\text { reduced; } \\
\text { Drb }>0 \text { - the volume of volume of } \\
\text { revenues to the budget from the use of } \\
\text { forest resources is grows }\end{array}$ & Low \\
\hline
\end{tabular}

\section{Conclusion}

Thus, for each criterion there is a corresponding assessment of the level of economic security. These estimates range from "very low" to "very high". This table does not represent a very high value. The assignment of this level depends on the magnitude of the value obtained. This mechanism has its continuation in the form of further comprehensive assessment of the level of economic security of the forest complex. Moreover, when assessing the level of economic security of the forest complex, the value of the indicator of possible risk and the probability of its occurrence, as well as the significance of a certain group of indicators in the integrated assessment of the level of economic security will be important (Morkovina and Rezanov, 2018). To determine the integrated indicator of the level of economic security of the forest sector of the economy in the context of climate change and increasing anthropogenic pressure, the following methodology is proposed. This methodology will be presented in the form of stages, implemented in practice in the reverse order.

1. Calculation and identification of the integral indicator of the level of economic security of the forest sector of the economy in the context of climate change and increasing anthropogenic pressure. This integral indicator can be presented in a multiplicative form:

where

$$
\mathrm{ES}=\mathrm{ESec} * \mathrm{ESel},
$$

ES - the level of economic security of the forest sector of the economy in the context of climate change and increasing anthropogenic pressure;

$\mathrm{ESec}$ - the level of economic security of the forest sector of the economy in the context of climate change and increasing anthropogenic pressure on the economic component;

ESel - the level of economic security of the forest sector of the economy in the context of climate change and the increasing anthropogenic pressure on the environmental component. 
The threshold value for identifying this indicator is "one".

If "ES" is more than or equal to one, the level of economic security of the forest sector of the economy in the context of climate change and increasing anthropogenic pressure is not just high, and the forest sector has a certain margin of safety for successfully leveling the threats to the economic security of the forest sector arising in the environment.

If the value "ES" is less than one, then a detailed analysis of the economic and environmental components of the economic security of the forest sector of the economy in the context of climate change and increasing anthropogenic pressure is necessary.

2. Calculation of the indicator of the economic security level (ESec) of the forest sector of the economy in the context of climate change and increasing anthropogenic pressure on the economic component. The method of calculating indicators in the integral is given above (Table 6).

3. Calculation of the indicator of the level of economic security of the economy forest sector in the context of climate change and the increasing anthropogenic (ESel) pressure on the environmental component. This indicator also has a multiplicative form: $\mathrm{ESel}=\mathrm{W}^{*} \mathrm{TS}$,

where

$\mathrm{W}$ - the level of economic security by the criterion of the forest cover of the territory. TS - the level of economic security according to the criterion of timber stocks in the territory. The threshold value for identifying this indicator is "one".

If "ESel" is more than or equal to "one", then the economic security level of the forest sector of the economy in the context of climate change and the increasing anthropogenic pressure on the environmental component is sufficient, the forest sector has a certain margin of safety for successful leveling of climatic and biological threats to the economic security of the forest sector arising in the external environment.

If the value of "ESel" is less than "one", then a detailed analysis of the environmental component is necessary in terms of the analysis of the forest cover and timber stock indicators in the context of climate change and an increase in anthropogenic pressure, since these indicators have been identified by us as key ones. The corresponding numerical values for calculating and estimating the level of economic security for the environmental component for each of the parameters are presented in Table 7. 
Table 7. Assessment of the level of economic security in the forest sector of the economy by the environmental component according to the relevant parameters (developed by the authors)

\begin{tabular}{|c|c|c|c|c|}
\hline No & Criteria of evaluation & $\begin{array}{l}\text { The level of } \\
\text { economic security }\end{array}$ & $\begin{array}{l}\text { Interval value of } \\
\text { parameter }\end{array}$ & $\begin{array}{l}\text { Numerical value } \\
\text { for calculation }\end{array}$ \\
\hline 1 & $\begin{array}{l}\text { The level of } \\
\text { compliance of the } \\
\text { forest cover with the } \\
\text { average value }\end{array}$ & $\begin{array}{l}\text { Average } \\
\text { Low } \\
\text { Very low } \\
\text { High } \\
\text { Very high }\end{array}$ & $\begin{array}{l}0 \\
\text { from }-10 \% \text { to } 0 \\
\text { from }-11 \% \text { and } \\
\text { less } \\
\text { from } 0 \text { to } 10 \% \\
\text { from } 11 \% \text { and } \\
\text { up }\end{array}$ & $\begin{array}{l}1 \\
1,1 \\
1,2 \\
0,9 \\
0,8\end{array}$ \\
\hline 2 & $\begin{array}{l}\text { The level of } \\
\text { compliance of forest } \\
\text { cover with the } \\
\text { ecological minimum }\end{array}$ & $\begin{array}{l}\text { Low } \\
\text { Very low } \\
\text { Average } \\
\text { High } \\
\text { Very high }\end{array}$ & $\begin{array}{l}1 \\
\text { Less than } 1 \\
\text { from } 1 \text { to } 2 \\
\text { from } 2 \text { to } 3 \\
\text { from } 3 \text { and up } \\
\end{array}$ & $\begin{array}{l}0,9 \\
0,8 \\
1 \\
1,1 \\
1,2\end{array}$ \\
\hline 3 & $\begin{array}{l}\text { The level of } \\
\text { compliance of the } \\
\text { wood supply with the } \\
\text { standard value }\end{array}$ & $\begin{array}{l}\text { Average } \\
\text { Low } \\
\text { Very low } \\
\text { High } \\
\text { Very high }\end{array}$ & $\begin{array}{l}100 \\
\text { from } 90 \% \text { to } 100 \\
\text { from } 90 \% \text { and } \\
\text { up } \\
\text { from } 0 \text { to } 110 \% \\
\text { from } 111 \% \text { and } \\
\text { up }\end{array}$ & $\begin{array}{l}1 \\
0,9 \\
0,8 \\
1,1 \\
1,2\end{array}$ \\
\hline 4 & $\begin{array}{l}\text { Growth rate of wood } \\
\text { stock per year }\end{array}$ & $\begin{array}{l}\text { Low } \\
\text { Very low } \\
\text { Average } \\
\text { High } \\
\text { Very high }\end{array}$ & $\begin{array}{l}0 \\
\text { менее } 0 \\
\text { from } 0 \text { to } 5 \% \\
\text { from } 6 \% \text { to } 10 \% \\
\text { from } 11 \% \text { and } \\
\text { up }\end{array}$ & $\begin{array}{l}0,9 \\
0,8 \\
1 \\
1,1 \\
1,2\end{array}$ \\
\hline
\end{tabular}

4. Determination of the probability of occurrence of threats described by the proposed criteria when assessing the level of economic security of the forest sector on the Harrington scale.

In the presented algorithm, the collection of primary information is of key importance. According to the author, to monitor threats to economic security, it is advisable to distinguish between information monitoring (in this case, monitoring is considered in a narrower sense, as a mechanism for collecting information). The authors carried out systematization and processing of statistical material provided by official state statistics and forestry departments of the Tambov region and Ryazan regions for testing the proposed methodology for assessing threats to economic security.

As a result of the implementation of the methodology, the level of economic security was assessed. Eventually, it had been determined that the Tambov region was characterized by an average level of economic security of the forest sector of the 
economy. The Ryazan region was also characterized by an average level of economic security. Thus, for the Tambov and Ryazan regions it is advisable to use differentiated tools from the same group. For regions with low and very low levels of economic security, differentiated tools that take into account the specifics of the territory are needed (Busarina and Morkovina, 2014).

Figure 1. Algorithm for monitoring threats to economic security

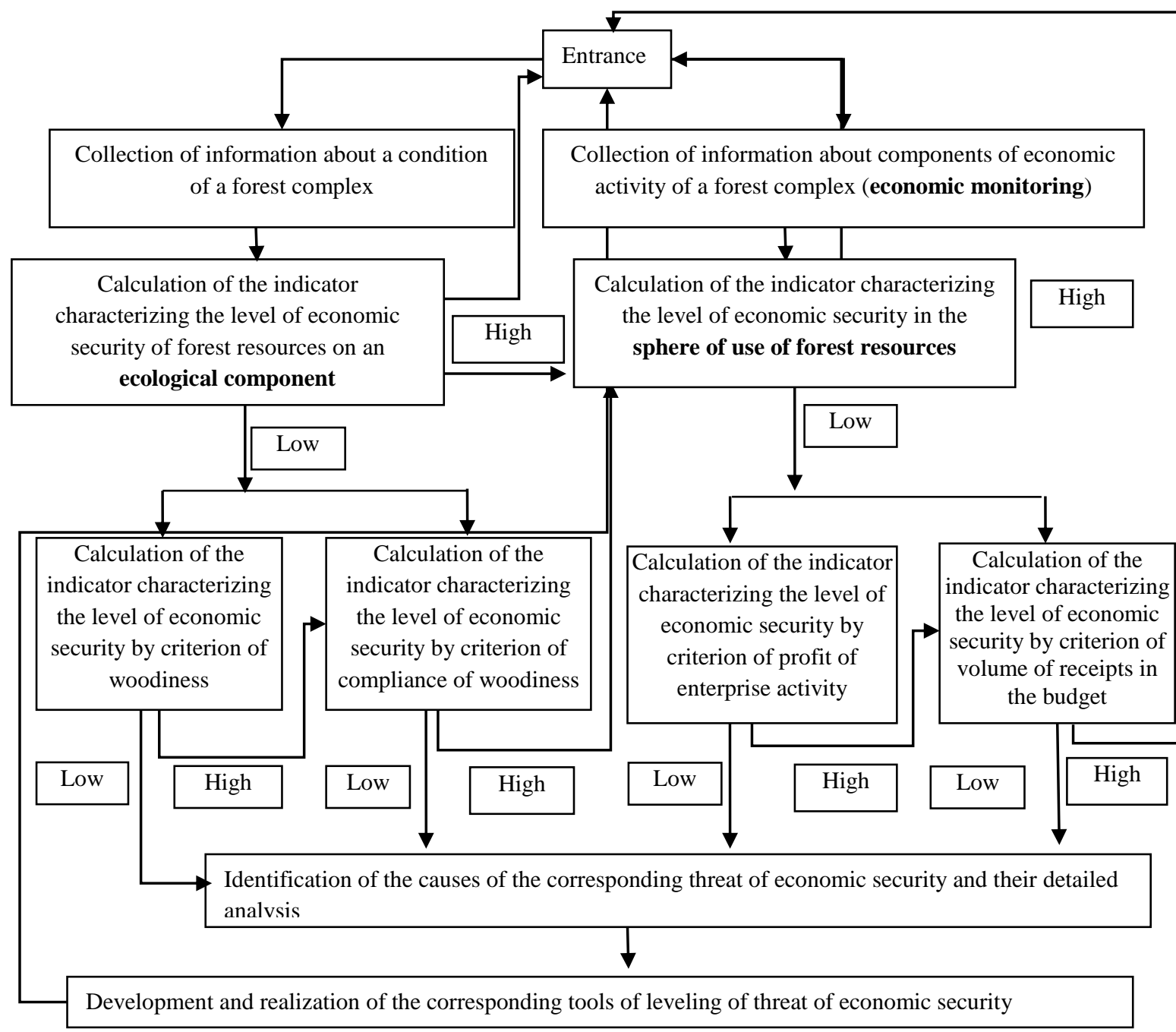

Thus, in the author's interpretation, the algorithm for monitoring threats to economic security will be as follows (Figure 1). 


\section{References:}

Balou, R., Proshan, F. 1969. Mathematical theory of reliability. Moscow, Soviet Radio, 412.

Bespalov, V.I., Maksyukova Yu.Yu. 2007. Methods of complex socio-ecological-economic assessment of the state of territories. Human Ecology, 4, 17-19.

Busarina, U., Morkovina, S., Kolesnichenko, E. 2014. Mechanisms of support of exportoriented small enterprises: the regional aspect. Asian Social Science, 23(10), 95-101.

Kolesnichenko, E.A., Osmanov, Zh.D. 2015. Economic security of key sectors of the Russian economy: structural approach to research. Forestry Engineering Journal [in Russian -Lesotehnicheski], 2(5), 187-202.

Kolesnichenko, E.A., Radyukova, Ya.Yu., Bespalov, M.V. 2017. Increasing the involvement of staff in the activity of the company as a factor influencing its efficiency.

Proceedings of the 30th International Business Information Management Association Conference, IBIMA 2017 - Vision 2020: Sustainable Economic development, Innovation Management, and Global Growth, 2170-2178.

Konstantinov, A.V., Kolesnichenko, E.A. 2016. Criteria and methods for monitoring threats to economic security in sectors of the economy in the context of transformation of external determinants. Forestry Engineering Journal, 4, 240-249

Morkovina, S.S., Drapalyuk, M.V., Sibiryatkina, I.V., Torzhkov, I.O. 2017. Priorities of diversification in forest complex. Vision 2020: Sustainable Economic development, Innovation Management, and Global Growth. Proceedings of the 30th International Business Information Management Association Conference, 2856-2862.

Morkovina, S.S., Rezanov, V.K., Panyavina, E.A., Sukhova, V.E. 2018. Function value analysis in forestry practice. Innovation Management and Education Excellence through Vision 2020 Proceedings of the 31st International Business Information Management Association Conference (IBIMA), 4419-4425.

Shatkovskaya T., Epifanova T. 2016. Correlation of Private and Public Legal Interests as Theoretical and Scientific and Practical Problem of Modern Law. Journal of Advanced Research in Law and Economics, 3(17). 625-643, DOI: 10.14505/jarle.v7.3(17).19.

Utkin, E.A, Denisov, A.F. 2002. Theory of Government. Moscow, IKF "EKMOS", 320. 